\title{
Volcanic sulfides and outgassing
}

Marie Edmonds ${ }^{1}$ and Tamsin A. Mather ${ }^{2}$

1 Department of Earth Sciences, University of Cambridge

2 Department of Earth Sciences, University of Oxford

5

6 Sulfides are a major potential repository for magmatic metals and sulfur. In more reduced magmas, there may be a dynamic interplay between sulfide liquids and degassing as magmas ascend/erupt. Sulfide-bubble aggregates may segregate to shallow levels. Exsolved

9 fluids may oxidize sulfides producing $\mathrm{SO}_{2}$ gas and metals, which may vent to the

10 atmosphere with chalcophile metal ratios reflecting those in the sulfide liquids. Sulfide

11 breakdown and/or sequestration timing and balance define the role of sulfides in both ore

12 formation and the environmental impacts of volcanic eruptions, including during Large

13 Igneous Provinces, key periods of heightened volcanism during Earth history.

15 Key words: sulfide, outgassing, metals, partitioning, vapor, eruptions

\section{INTRODUCTION}

19 Sulfides are a common feature of near surface magmas (figure 1) and play an important role in

20 volcanic systems in the supply of sulfur and chalcophile metals to the atmosphere and to sites of

21 ore formation. Sulfur is one of the most abundant and important volatile species produced by

22 volcanic activity. Volcanic eruptions may produce large clouds of sulfur dioxide which, when

23 injected into the stratosphere, convert to sulfate aerosol and may impact climate by absorbing

24 near-IR radiation and scattering it back into space. Tropospheric plumes of sulfur gases and 25 aerosol may be large enough to cause environmental damage and health hazards. Sulfur-rich 
26 fluids at submarine mid-ocean ridges, formed by the outgassing of ascending basaltic melts,

27 support sulfide-oxidising microbial life and modulate ocean chemistry and oxidation state.

29 Sulfur is a ubiquitous component of magmas and displays complex behavior due to its ability to 30 exist in many valence states and species $\left(\mathrm{S}^{2-}, \mathrm{S}^{6+}, \mathrm{S}^{0}\right.$ and as $\mathrm{S}_{2}, \mathrm{SO}_{2}, \mathrm{SO}_{3}$ and $\mathrm{H}_{2} \mathrm{~S}$ in the gas 31 phase). Its behaviour in magmas is largely dependent on magma oxidation state (the availability 32 of oxygen) (Carroll and Rutherford, 1985). Under reduced conditions sulfur dissolves as sulfide $33\left(\mathrm{~S}^{2-}\right)$ and under oxidized conditions, as sulfate $\left(\mathrm{S}^{6+}\right.$ in $\left.\mathrm{SO}_{4}{ }^{2-}\right)$; under intermediate conditions both 34 speciation states are present. Dissolved sulfur species will progressively concentrate in melts 35 during crystallization (of non-sulfur-bearing phases), until eventually, the melt concentration of 36 sulfur may reach the level required for the precipitation of (or "saturation in") a non-volatile, 37 sulfur-bearing phase. The form of this phase is dependent on both the fugacities (or put simply, 38 the abundance or availability) of oxygen and sulfur in the system. Under oxidized conditions, the 39 solid sulfur-bearing phase is anhydrite $\left(\mathrm{CaSO}_{4}\right)$. In relatively reduced magmas typical of mid40 ocean ridges, for example, this sulfur-bearing phase might be monosulfide solid solution (mss) or

41 a Fe-O-S immiscible liquid, which quenches to a sulfide solid solution (Parat et al., 2011).

42 Photomicrographs to show quenched sulfide liquids in a range of volcanic rocks, in the form of 43 inclusions in crystals and in the matrix glass, are shown in figure $\mathbf{1 .}$

45 Sulfide liquids display a range of compositions and may contain appreciable concentrations of 46 metals such as copper $(\mathrm{Cu})$ and nickel (Ni). Sulfide liquids are dense relative to silicate melts and 47 may settle gravitationally and be reworked multiple times, leading to the segregation of massive 48 volcanigenic sulfide deposits (Ripley and Li, 2013), which may have substantial economic value. 49 In volcanic systems, however, which involve magmas stored at low pressures, hydrothermal 50 fluids may also coexist with sulfide-saturated magmas. Interaction between oxidising, water-rich 51 fluids and sulfide liquids may promote an interplay between volcanic outgassing and sulfide 
52 saturation such that sulfides might break down, supplying sulfur directly to the atmosphere

53 (Nadeau et al., 2010). Volcanoes are significant sources of metals to the atmosphere via gas and 54 aerosol phases (Mather et al., 2012); where sulfide saturation occurs, some of these metals may 55 derive directly from sulfide breakdown (Larocque et al., 2000).

57 Sulfur is also volatile in silicate melts, and partitions strongly into a vapor phase at low pressures 58 in the crust, and sulfide saturation may have a key modulating effect on melt-vapor partitioning.

59 Sulfur partitioning behavior is well understood for a wide range of oxidation states and melt 60 compositions. In general, experiments indicate that sulfur partitions strongly into the gas phase, 61 particularly for more reducing conditions below the sulfate-sulfide transition, caused by the lower 62 solubility of sulfur when it exists as the ion $\mathrm{S}^{2-}$ than when it occurs, under more oxidizing 63 conditions, dissolved as sulfate $\left(\mathrm{S}^{6+}\right)$. Saturation of the melt in sulfide or in anhydrite (at more 64 oxidizing conditions) limits the sulfur concentration in the co-existing gas phase to just a few per 65 cent by volume (Zajacz et al., 2012).

The interplay between and timing of these partitioning processes (between silicate melt, vapor and sulfide) has consequences for outgassing or sequestration in reduced volcanic systems. The range of possible processes involving sulfide saturation and vapor saturation of melts, and their consequences is summarised in figure 2. The mass budget of sulfur available for degassing into

71 the atmosphere in volcanic systems is often estimated using the sulfur concentration in melt 72 inclusions (tiny increments of melt trapped in growing crystals), the so-called petrological 73 method (Sigurdsson et al., 1985), but only rarely is the sulfur in the sulfide liquid phase taken 74 account of, beyond recognition of sulfide saturation. The timing of sulfide saturation and vapor 75 saturation in volcanic systems is likely critical for determining the extent to which metal-rich 76 sulfides are sequestered; and the magnitude of the sulfur-rich gas cloud outgassed with magma during eruptions. The high degree of wetting of hydrous vapor on sulfide liquid droplets may 
render the sulfide liquids buoyant, promoting their involvement in volcanic outgassing processes

79 and preventing sulfide sequestration (Mungall et al., 2015).

81 In this article we review the controls on sulfide liquid formation in volcanic melts and their 82 compositions; and their potential interaction with hydrothermal-volcanic fluids. We discuss the

83 fundamental role that sulfides play in modulating the transport of sulfur from mantle-derived 84 melts to the crust and into the atmosphere, and the feedbacks related to the formation of sulfide 85 ore deposits associated with these magmas.

\section{SULFIDE SATURATION IN ERUPTING BASALTIC MELTS}

89 For the purposes of this paper we focus on those systems that contain substantial quantities of

90 sulfide in the melt, which correspond to magmas in ocean island (or "hotspot"), mid-ocean ridge 91 (MOR) settings, and some arc (subduction-related) magmas. The concentration of sulfur required 92 to saturate in sulfide is known as the sulfur concentration at sulfide saturation (SCSS). The 93 sulfate-dominated volcanic systems are beyond the scope of this paper, but are often 94 characteristic of more evolved magmas and extremely important in volcanic arcs, where 95 anhydrite may modulate the mass of sulfur outgassing into the atmosphere (Masotta et al., 2016).

\section{Sulfide-saturation in mid-ocean ridge basalts (MORB)}

99 We will begin by considering the case of MORB; these are well understood and characterized, and are erupted with an oxygen fugacity that ensures that much of the dissolved sulfur is present as sulfide. The amount of sulfur that a melt can dissolve before saturation with respect to a

102 sulfide phase depends on both melt composition (largely the $\mathrm{Fe}^{2+}$ content, with which sulfur 103 forms complexes in the melt) but also temperature and pressure. Various empirical models to 
104 describe the SCSS have been proposed (Liu et al., 2007) which take account of complex

105 compositional and intrinsic parameters. A schematic illustration to show how typical mid-ocean

106 ridge basaltic melt may evolve due to fractional crystallization is shown in figure 3. Sulfide

107 saturation occurs when the sulfur concentration in the melt intersects the SCSS curve. MORBs

108 are thought to be sulfide-saturated during generation in their mantle source region (Mavrogenes

109 and O'Neill, 1999). The decrease in pressure during magma ascent will result in an increase in

110 the SCSS for anhydrous melts (caused by the larger volume of dissolved sulfur over sulfide) and

111 thus tend to drive the magmas toward under-saturation. MORB data, however, show a correlation

112 between sulfur concentration and decreasing $\mathrm{Cu}$ with $\mathrm{MgO}$ concentrations (Jenner and O'Neill,

113 2012), consistent with sulfide saturation prior to and during eruption, with $\mathrm{Cu}$ partitioning into

114 the sulfide phase. Observations of quenched, rounded sulfide blebs in submarine MORB glasses

115 confirm sulfide saturation. An explanation for crustal, late-stage sulfide liquid saturation might be

116 fractional crystallization, which even after modest amounts $(\sim 10 \%)$ will tend to drive the liquid

117 towards sulfide saturation (Li and Ripley, 2005). A detailed study of the textures of MORB

118 sulfides show that they are typically exsolved into Ni-rich and Cu-rich regions (figure 4). The

119 Ni-rich regions, known as monosulfide solution solutions (mss), are also rich in Co and Re; the

$120 \mathrm{Cu}$-rich regions, known as intermediate sulfide solid solutions (iss) are also enriched in $\mathrm{Zn}, \mathrm{Cd}$,

121 Ag, Sn, Te, Bi and Au (Patten et al., 2013).

123 Basalts erupted in Iceland also display globules of quenched sulfide liquids in their groundmass

124 (figure 1) (Sigmarsson et al., 2013), suggesting that, like typical MORB, they are saturated with

125 a sulfide phase shortly before, during and after eruption, due to both fractional crystallisation

126 (increasing the sulfur concentration in the liquid) and cooling (reducing the SCSS). Models

127 predict that tholeiitic basaltic melts from Iceland will become saturated in a sulfide phase after

128 around $50 \%$ crystallization, which is illustrated by data from Hekla volcano (Moune et al., 2007).

129 Hekla melt inclusions follow a trend that predicts that they reach sulfide saturation at melt $\mathrm{MgO}$ 
130 contents of around $6.5 \mathrm{wt} \% \mathrm{MgO}$, which probably takes place during fractional crystallization in

131 upper crustal magma reservoirs shortly before eruption, thereby forming sulfide liquid globules

132 as observed in erupted rocks (figure 1).

133

134 It is straightforward then, to demonstrate that MORB and Icelandic melts are sulfide-saturated

135 and that sulfide saturation occurred at a relatively late stage, in response to crystallization.

136 MORBs, however, are typically erupted in water depths of $>1 \mathrm{~km}$, which means that little water

137 degassing takes place from the melt and hence the sulfide liquids are unlikely to be in contact

138 with aqueous magmatic fluids and therefore there is limited opportunity to transfer their sulfur

139 burden to the atmosphere or water column (figure 2). However, what would be the consequences

140 of subaerial eruption and outgassing of such sulfide-bearing basalts?

\section{Degassing of sulfide-saturated magmas in a range of tectonic settings}

144 As discussed above, Icelandic melts are sulfide-saturated at a relatively late stage of evolution

145 and in response to crystallization. The very large fluxes of sulfur dioxide loading associated with

146 Icelandic eruptions such as Laki $(1783 ; 122 \mathrm{Tg}$; (Thordarson and Self, 1993) and the more recent

147 Holuhraun eruption (2014; 8.9 +/- $0.3 \mathrm{Tg}$; (Gauthier et al., 2016)) testify to the sulfur-rich nature

148 of the basaltic melts ascending into the crust beneath Iceland and to the efficient outgassing of

149 sulfur from melts as they decompress and erupt. The role of sulfides in this sulfur outgassing, and

150 its implications in terms of metal release, is worthy of further detailed consideration.

152 Most magmatic melts are vapor-saturated from the mid-crust, coexisting with a $\mathrm{CO}_{2}$-rich vapor

153 phase at depth, which becomes more $\mathrm{H}_{2} \mathrm{O}$-rich closer to the surface. The vapor phase also

154 contains significant quantities of sulfur and halogen species. Magmatic sulfide stability is 
155 extremely sensitive to degassing-induced redox changes in the melt, and to removal through

156 outgassing of exsolved sulfur species, which lowers the fugacity of sulfur in the gas phase and

157 induces sulfide liquid (SL) oxidation and breakdown via a reaction of the form (Berlo et al., 158 2014):

$$
3 \mathrm{FeS}_{\mathrm{SL}}+2 \mathrm{H}_{2} \mathrm{O}_{\text {melt } \text {,fluid }}+2 \mathrm{O}_{2 \text { melt, fluid }} \rightarrow \mathrm{Fe}_{3} \mathrm{O}_{4, m t}+2 \mathrm{H}_{2} \mathrm{~S}_{\text {fluid }}+\mathrm{SO}_{2 \text { fluid }}
$$

162 This reaction results in the formation of magnetite $(\mathrm{mt})$, which does not hold metals in its

163 structure to the same degree as sulfide, resulting in release of the concentrated metals, as well as

$164 \mathrm{H}_{2} \mathrm{~S}$ and $\mathrm{SO}_{2}$, directly into the aqueous fluid bubbles-silicate melt system (illustrated in figure 4).

165 This process of metal transfer from the sulfide liquid to the volcanic gas phase has been inferred

166 for a range of volcanoes, including more evolved systems such as Kawah Ijen Volcano (Berlo, et

167 al., 2014) and Merapi Volcano (Nadeau, et al., 2010), both in Indonesia. At Merapi, as well as for

168 the Alumbrera porphyry ore deposit, Argentina (Halter et al., 2002), the metal ratios observed in

169 volcanic gases emitted from the crater have the same ratios of $\mathrm{Cu}$ to $\mathrm{Au}$ as the sulfides trapped as

170 inclusions inside phenocrysts (Nadeau, et al., 2010). At Kawah Ijen, metal concentrations in melt

171 inclusions, combined with abundances of $\mathrm{H}_{2} \mathrm{O}, \mathrm{CO}_{2}$ and $\mathrm{S}$, were used to reconstruct the presence

172 of a sulfide liquid at depth, which sequestered metals. Breakdown of the sulfide phase resulted in

173 redistribution of metals between metals and fluids before outgassing at the volcanic vents (Berlo,

174 et al., 2014). More generally the distribution of metals in volcanic plumes may provide 175 corroborating evidence for such a sulfide breakdown mechanism (figure 5). The volcanic gas and 176 aerosol composition of the plume accompanying a recent Icelandic basaltic eruption shows that it 177 was enriched in metals (Gauthier, et al., 2016), with their distribution mirroring the trend in 178 elemental sulfide-silicate melt partitioning behaviour (figure 5). In particular, the enrichment in 179 elements like Re, Se and Te in the volcanic aerosol phase are strongly suggestive of an origin by 
180 sulfide breakdown in the melt owing to their extremely high sulfide-silicate melt partition

181 coefficients ( $>500$; (Brenan, 2015)). Once the sulfide has broken down, there may be some

182 further partitioning between fluid and melt, which is likely to be dependent on the chloride

183 concentration of the fluid, owing to the tendency for metal ions to be complexed with chloride

184 (and perhaps sulfur) in the gas phase.

186 In fact, the sulfide-silicate melt partition coefficients for many key metals are high (>100; figure

187 5) and it follows that, where erupting melts are sulfide-saturated (as appears to be the case for 188 many basalts in a range of settings), most of these metals (90-99.9\%) in the magma will likely be

189 sequestered into the sulfide phase prior to eruption, even for small mass abundances of sulfide.

190 This sulfide phase will break down when an aqueous fluid develops in the melt due to vapor191 saturation. The metal-rich gases observed at such volcanoes must therefore in large part be 192 derived from the breakdown of sulfide liquids prior to eruption.

194 The sulfide liquids themselves are often entirely absent in the volcanic rock products, owing to 195 the efficient and rapid nature of the breakdown process described above, but in some cases 196 sulfide globules are preserved in the matrix glasses or more commonly, as inclusions in 197 phenocrysts, protected from the fluid phase by the crystal host (figure 1). It therefore follows that 198 many magmas erupted at the surface have lost a large proportion of the sulfide liquids that were 199 present in the magma prior to degassing due to resorption and oxidation. Additional evidence for 200 this comes from comparisons of sulfide form and distribution within intrusive and volcanic rocks 201 from the Tertiary Bingham and Tintic Districts, Utah. Volcanic rocks (and the porphyries) have 202 two orders of magnitude less sulfide by mass than dykes, which were emplaced at higher 203 pressures where degassing was inhibited. The textures of all of the sulfides in the volcanic rocks 204 and porphyries have been modified extensively by resorption and degassing (figure 4). 205 Immiscible liquids crystallized as pyrrhotite and chalcopyrite with declining temperature and 
206 pressure, and locally recrystallized to pyrite and an Fe-oxide as they were oxidized. The

207 alteration and preservation textures change from subspherical sulfide blebs near the margins of

208 the quenched (and better preserved) dikes and sills, to partially altered sulfides farther in, to

209 complete absence of sulfides in the vast majority of intrusions and volcanic rocks (except where

210 small sulfides are completely enclosed by phenocrysts). The cooling of these magmas, coupled

211 with the degassing of magmatic volatiles, including sulfur-bearing gases (e.g., $\mathrm{H}_{2} \mathrm{~S}, \mathrm{SO}_{2}$ ), caused

212 resorption and oxidation of magmatic sulfides to occur (Larocque, et al., 2000). It has been

213 estimated that degassing and oxidation probably removed greater than $90 \%$ of the original

214 endowment of magmatic sulfides. This example illustrates well why volcanic rocks rarely contain

215 sulfides in the matrix glass; and provides explanation for the low-magmatic sulfide abundances of

216 slowly cooled, extensively degassed, large porphyritic intrusions. Most importantly, this process

217 allows metals and sulfur, under some conditions, to participate in the formation of porphyry

218 deposits and in others, to be outgassed into the atmosphere.

220 Sulfides therefore may play a much greater role in supplying sulfur to co-eruptive gas plumes

221 than previously assumed; and it is likely that the commonly used petrological method to calculate

222 sulfur outputs from past basaltic eruptions (which uses the difference in sulfur concentration

223 between melt inclusions and degassed matrix) might be improved in many cases by

224 reconstruction of sulfide saturation and a robust mass balance using chalcophile element 225 inventories.

Dynamics of sulfide-aqueous fluid interaction

229 An important question relates to how sulfides remain in suspension in relatively low viscosity

230 basaltic liquids in order to participate in the resorption and oxidation reactions discussed above.

231 Sulfide liquids are dense, and therefore they are predicted to settle out of the liquids by gravity 
232 and accumulate in basal zones in the magma chamber, which may later form the loci for 233 economically-viable Ni-Cu-PGE sulfide accumulations as evidenced by abundant examples

234 (Ripley and Li, 2013).

236 Recently however, experiments have shown that the contact angle for sulfur-bearing vapor on 237 sulfides is small (i.e. the wettability or the ability of the fluid to maintain contact with the solid 238 surface is high); much smaller than for bubbles nucleating on silicate crystal phases such as 239 olivine, pyroxene or plagioclase (Mungall, et al., 2015). Theoretical calculations also show that it 240 is energetically far more favorable for aqueous bubbles to nucleate on sulfides or on sulfide liquid 241 droplets, to the exclusion of all other phases if sulfides are present, even in small amounts 242 (Mungall, et al., 2015). The effect of the formation of sulfide-bubble "compound drops" on their 243 distribution may be profound. If this process occurs at low pressures, the bulk density of the

244 bubble-sulfide liquid aggregate may be lowered sufficiently to render the sulfide liquid buoyant 245 relative to the silicate melt. This buoyancy allows the sulfide liquid to ascend to the surface with 246 the melt during eruptions, participating in the outgassing process, breaking down and supplying 247 its sulfur and metal loads to the atmosphere (figure 2). The timing of vapor and sulfide saturation 248 are potentially critical; if sulfide saturation occurs before the generation of a significant gas 249 fraction, then sulfides may be lost and sequestered gravitationally; if vapor saturation occurs 250 concurrently with (or before) sulfide saturation in the upper crust, then buoyant aggregates may 251 form. The melt viscosity and the timescales of settling are also key.

THE ROLE OF SULFIDES IN OUTGASSING ASSOCIATED WITH LARGE IGNEOUS 254 PROVINCES (LIPs)

256 Hotspot magmatic systems today in the oceans and on the continents provide an analogue for flood basalt provinces in terms of their sulfur budgets and the role of sulfides in outgassing. 
258 Large igneous province (LIP) emplacement has been associated with severe degradation of the

259 Earth's surface environment and also occurs coincident with extreme mass extinctions in the

260 sedimentary record, suggesting a causal link. The potential role of sulfides in LIP degassing has

261 implications in terms of our understanding of these key events in Earth history.

263 The sulfur budgets of LIPs are notoriously difficult to reconstruct, owing to melt inclusions being

264 commonly small and entirely recrystallized, with some rare exceptions (Self et al., 2008). It is

265 commonly believed that LIP basalts are sulfide-saturated, and in fact this forms the basis of a

266 widely used method to calculate the likely sulfur outgassing budgets of these eruptions, using the

267 MORB FeO-S relationship to estimate the pre-eruptive dissolved sulfur concentration and then

268 applying the petrological method (Blake et al., 2010).

270 Abundant evidence of sulfide saturation and accumulation exists in large igneous provinces

271 worldwide, exemplified by the Norilsk sulfide-hosted platinum group element (PGE) deposits,

272 part of the end-Permian Siberian Traps Magmatic Province. The high Pt concentration of the

273 deposits here require multiple episodes of sulfide resorption and precipitation to concentrate the

274 PGE elements, as well as assimilation of sulfate from country rocks to generate the heavy sulfur

275 isotopic signature of the deposits (Li et al., 2009). Sediments at the Permian-Triassic boundary at

276 many locations around the world show spikes in their metal concentrations, most notably in Ni

277 (Rothman et al., 2014) but also other metals such as mercury (Sanei et al., 2012), which have

278 been suggested to be linked to transport and deposition of volcanic gas/aerosols related to

279 Siberian Traps volcanism. The direct observations of sulfide saturation in magmas, combined

280 with the metal spikes in sediments, support the idea that sulfides played an important role in

281 generating the gaseous outputs of LIPs in our geological past. Further studies to understand the

282 interplay between sulfides and sulfur and metal degassing in present-day analogues will have

283 clear implications in terms of understanding the economic and environmental implications for 
284 these key events in the geological record as well as present-day global biogeochemical cycles and 285 ore formation.

287 ACKNOWLEDGEMENTS

288 We acknowledge NERC urgency grant NE/M021130/1. The authors thank James Brenan, 289 Michael Rowe and an anonymous reviewer for their helpful comments. 
Berlo K, van Hinsberg V, Vigouroux N, Gagnon J, Williams-Jones A (2014) Sulfide breakdown controls metal signature in volcanic gas at Kawah Ijen volcano, Indonesia. Chemical Geology 371, 115-127.

Blake S, Self S, Sharma K, Sephton S (2010) Sulfur release from the Columbia River Basalts and other flood lava eruptions constrained by a model of sulfide saturation. Earth and Planetary Science Letters 299, 328-338.

Brenan JM (2015) Se-Te fractionation by sulfide-silicate melt partitioning: implications for the composition of mantle-derived magmas and their melting residues. Earth and Planetary Science Letters 422, 45-57.

Carroll M, Rutherford M (1985) Sulfide and sulfate saturation in hydrous silicate melts. Journal of Geophysical Research: Solid Earth (1978-2012) 90, C601-C612.

Gauthier PJ, Sigmarsson O, Gouhier M, Haddadi B, Moune S (2016) Elevated gas flux and trace metal degassing from the 2014-2015 fissure eruption at the Bárðarbunga volcanic system, Iceland. Journal of Geophysical Research: Solid Earth

Halter WE, Pettke T, Heinrich CA (2002) The origin of $\mathrm{Cu} / \mathrm{Au}$ ratios in porphyry-type ore deposits. Science 296, 1844-1846.

Jenner FE, O'Neill HSC (2012) Analysis of 60 elements in 616 ocean floor basaltic glasses. Geochemistry, Geophysics, Geosystems 13,

Kiseeva ES, Wood BJ (2013) A simple model for chalcophile element partitioning between sulphide and silicate liquids with geochemical applications. Earth and Planetary Science Letters 383, 68-81.

Larocque AC, Stimac JA, Keith JD, Huminicki MA (2000) Evidence for open-system behavior in immiscible Fe-S-O liquids in silicate magmas: implications for contributions of metals and sulfur to ore-forming fluids. The Canadian Mineralogist 38, 1233-1249.

Li C, Ripley EM (2005) Empirical equations to predict the sulfur content of mafic magmas at sulfide saturation and applications to magmatic sulfide deposits. Mineralium Deposita 40, 218-230.

Li C, Ripley EM, Naldrett AJ (2009) A new genetic model for the giant Ni-Cu-PGE sulfide deposits associated with the Siberian flood basalts. Economic Geology 104, 291-301.

Liu Y, Samaha N-T, Baker DR (2007) Sulfur concentration at sulfide saturation (SCSS) in magmatic silicate melts. Geochimica et Cosmochimica Acta 71, 1783-1799.

Masotta M, Keppler H, Chaudhari A (2016) Fluid-melt partitioning of sulfur in differentiated arc magmas and the sulfur yield of explosive volcanic eruptions. Geochimica et Cosmochimica Acta 176, 26-43.

Mather T, Witt M, Pyle D, Quayle B, Aiuppa A, Bagnato E, Martin R, Sims K, Edmonds M, Sutton A (2012) Halogens and trace metal emissions from the ongoing 2008 summit eruption of Kīlauea volcano, Hawaii. Geochimica et Cosmochimica Acta 83, 292-323.

Mavrogenes JA, O’Neill HSC (1999) The relative effects of pressure, temperature and oxygen fugacity on the solubility of sulfide in mafic magmas. Geochimica et Cosmochimica Acta 63, 1173-1180.

Moune S, Sigmarsson O, Thordarson T, Gauthier P-J (2007) Recent volatile evolution in the magmatic system of Hekla volcano, Iceland. Earth and Planetary Science Letters 255, 373-389.

Mungall JE, Brenan JM, Godel B, Barnes S, Gaillard F (2015) Transport of metals and sulphur in magmas by flotation of sulphide melt on vapour bubbles. Nature Geoscience 8, 216-219.

Nadeau O, Williams-Jones AE, Stix J (2010) Sulphide magma as a source of metals in arc-related magmatic hydrothermal ore fluids. Nature Geoscience 3, 501-505.

Parat F, Holtz F, Streck MJ (2011) Sulfur-bearing magmatic accessory minerals. Reviews in Mineralogy and Geochemistry 73, 285-314. 
Patten C, Barnes S-J, Mathez EA, Jenner FE (2013) Partition coefficients of chalcophile elements between sulfide and silicate melts and the early crystallization history of sulfide liquid: LA-ICP-MS analysis of MORB sulfide droplets. Chemical Geology 358, 170-188.

Ripley EM, Li C (2013) Sulfide saturation in mafic magmas: is external sulfur required for magmatic Ni-Cu-(PGE) ore genesis? Economic Geology 108, 45-58.

Rothman DH, Fournier GP, French KL, Alm EJ, Boyle EA, Cao C, Summons RE (2014) Methanogenic burst in the end-Permian carbon cycle. Proceedings of the National Academy of Sciences 111, 5462-5467.

Sanei H, Grasby SE, Beauchamp B (2012) Latest Permian mercury anomalies. Geology 40, 6366.

Self S, Blake S, Sharma K, Widdowson M, Sephton S (2008) Sulfur and chlorine in Late Cretaceous Deccan magmas and eruptive gas release. Science 319, 1654-1657.

Sigmarsson O, Haddadi B, Carn S, Moune S, Gudnason J, Yang K, Clarisse L (2013) The sulfur budget of the 2011 Grímsvötn eruption, Iceland. Geophysical Research Letters 40, 60956100 .

Sigurdsson H, Devine J, Davis A (1985) The petrologic estimation of volcanic degassing. Jökull $1-8$.

Thordarson T, Self S (1993) The Laki (Skaftár Fires) and Grímsvötn eruptions in 1783-1785. Bulletin of Volcanology 55, 233-263.

Yang X-M (2012) Sulphur Solubility in Felsic Magmas: Implications for Genesis of Intrusionrelated Gold Mineralization. Geoscience Canada 39,

Zajacz Z, Candela PA, Piccoli PM, Sanchez-Valle C (2012) The partitioning of sulfur and chlorine between andesite melts and magmatic volatiles and the exchange coefficients of major cations. Geochimica et Cosmochimica Acta 89, 81-101.

Zajacz Z, Halter WE, Pettke T, Guillong M (2008) Determination of fluid/melt partition coefficients by LA-ICPMS analysis of co-existing fluid and silicate melt inclusions: controls on element partitioning. Geochimica et Cosmochimica Acta 72, 2169-2197.

\section{LIST OF FIGURES}

Figure 1: Volcanic sulfides in basaltic tephra from Iceland and from Hawaii. a) backscattered electron and (b) reflected light images of polished sections of Holuhraun tephra (erupted November 2014 on the northern margin of the Vatnajokull ice cap, Iceland), showing basaltic glass (gl), silicate minerals olivine (ol) and plagioclase (plg), bright sulfide globules and abundant vesicles (v). c) a reflected light photomicrograph of an olivine crystal in tephra erupted during the 1959 eruption of Kîlauea Iki, Kīlauea Volcano, Hawaii, USA, containing inclusions of silicate melt, vapor bubbles and spherical globules of quenched sulfide liquid. Images credited to Margaret Hartley (a and b) and Isobel Sides (c). 
379 Figure 2: Schematic diagram to illustrate the primary processes of interest involving the

380 interactions between magmatic sulfides and exsolved aqueous fluids in volcanic systems, and

381 their implications for the formation of ore deposits, and/or outgassing of metals and sulfur to our

382 atmosphere.

383

384 Figure 3: Sulfide saturation due to fractionational crystallization of initially sulfide385 undersaturated mid-ocean ridge basaltic magma in the crust. Black curves show the sulfur 386 concentration at sulfide saturation (SCSS) from (Li and Ripley, 2005). Grey curves on both plots 387 show the concentration of sulfur rising as a result of fractional crystallization (assuming that 388 sulfur behaves as an incompatible element). Two initial concentrations of sulfur are illustrated: 389800 and 1100 ppm. Modified from (Li and Ripley, 2005) and (Ripley and Li, 2013).

391 Figure 4: Sketches to show the formation of monosulfide and intermediate sulfide solid solutions 392 during cooling from magmatic temperatures; and the oxidation, decomposition and resorption of 393 these sulfide phases in the presence of magmatic vapor bubbles in the melt. Abbreviations are: sl: 394 sulfide liquid; mss: monosulfide solid solution; iss: intermediate solid solution; po: pyrrhotite; py: 395 pyrite; cp: chalcopyrite. Magmatic iss and po destabilize relative to magnetite due to either 396 changes in $f\left(\mathrm{O}_{2}\right)$ and $f\left(\mathrm{~S}_{2}\right)$ and this leads to the release of metals from sulfides to the melt and/or 397 magmatic fluids. These fluids are then either sequestered into ore bodies or, the case of volcanic 398 systems, outgassed into the atmosphere. Modified from (Yang, 2012) and (Patten, et al., 2013).

400 Figure 5: The metal composition of volcanic plumes from Holuhraun (Iceland: (Gauthier, et al., 401 2016)) and Kīlauea (Hawaii: (Mather, et al., 2012)), analyzed using ICP-MS. The data are shown 402 in units of the $\log$ of the enrichment factor (EF; by mass) relative to the element magnesium 403 (Mg). Also shown are chalcophile element sulfide-silicate partition coefficients (Brenan, 2015, 
404 Kiseeva and Wood, 2013), and aqueous fluid-melt partition coefficients (Zajacz et al., 2008) 405 plotted on top.

406 

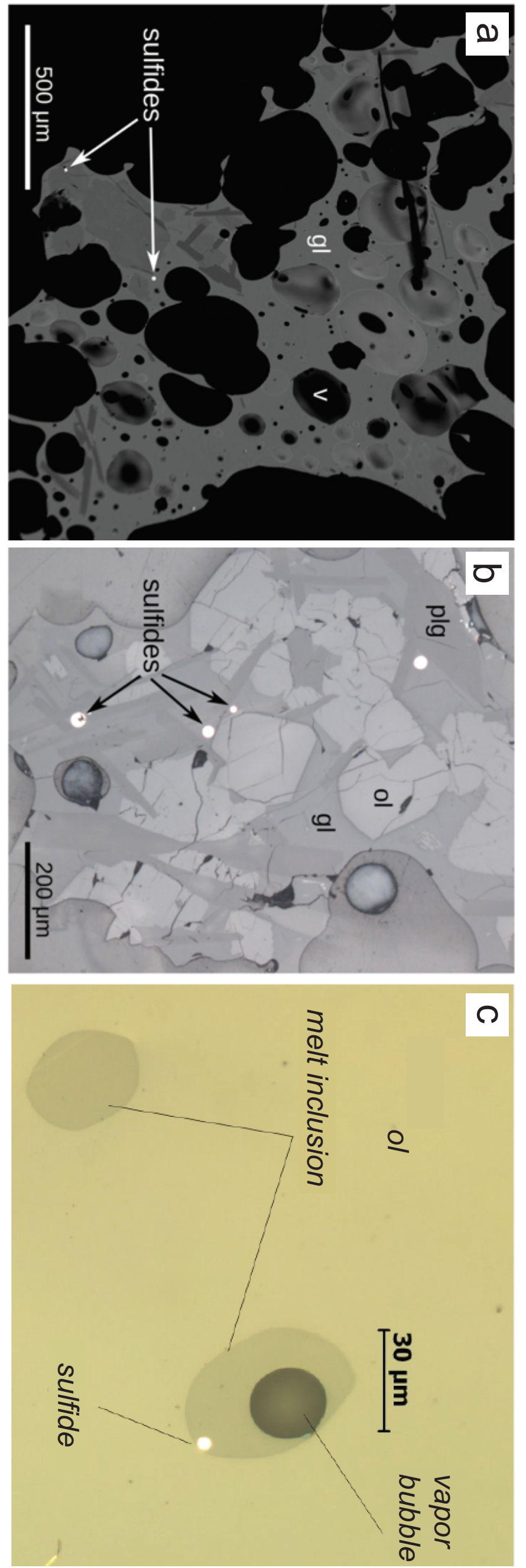


\section{Volcanic gas emissions}

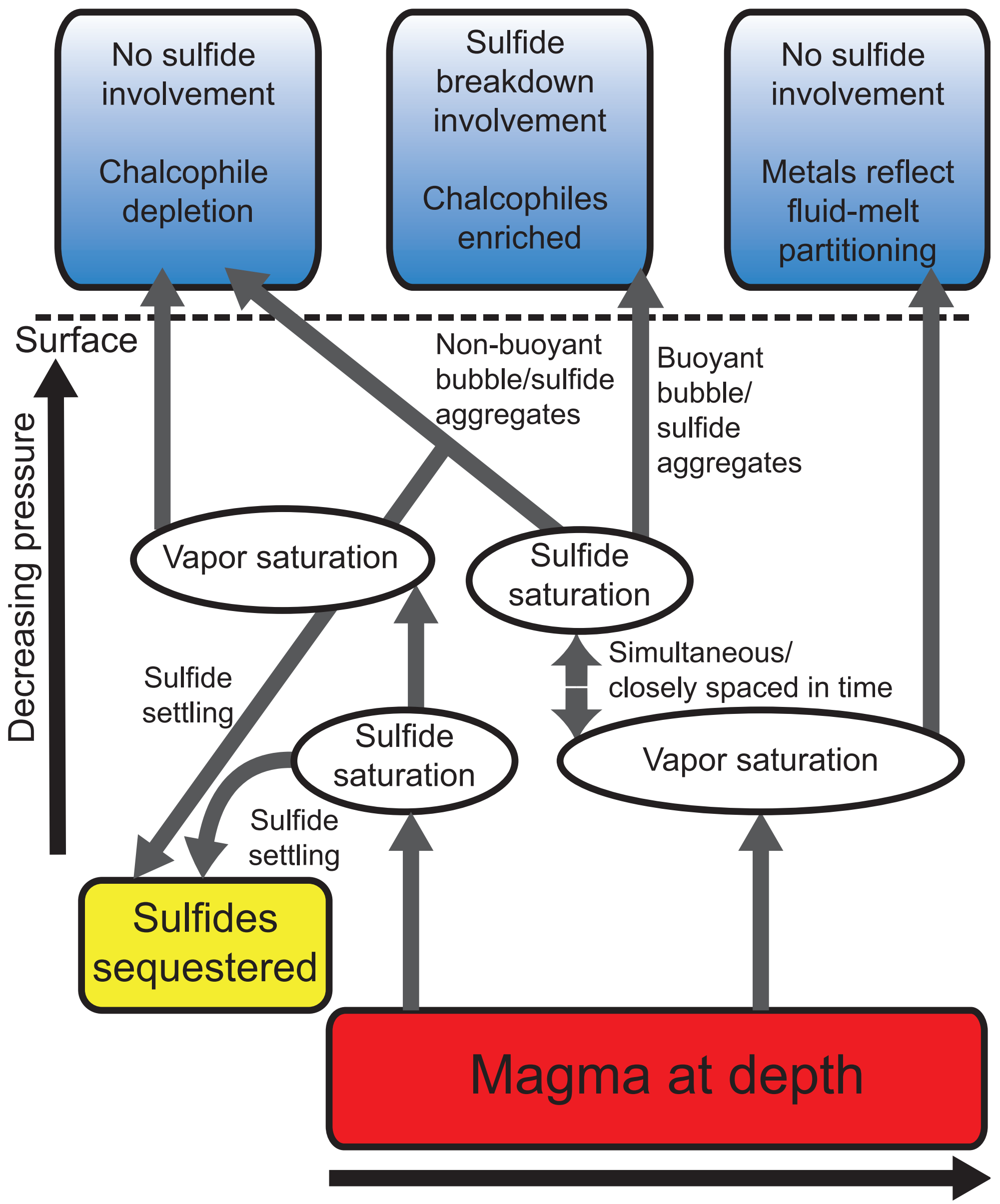

Increasing oxygen fugacity

Increasing water content 


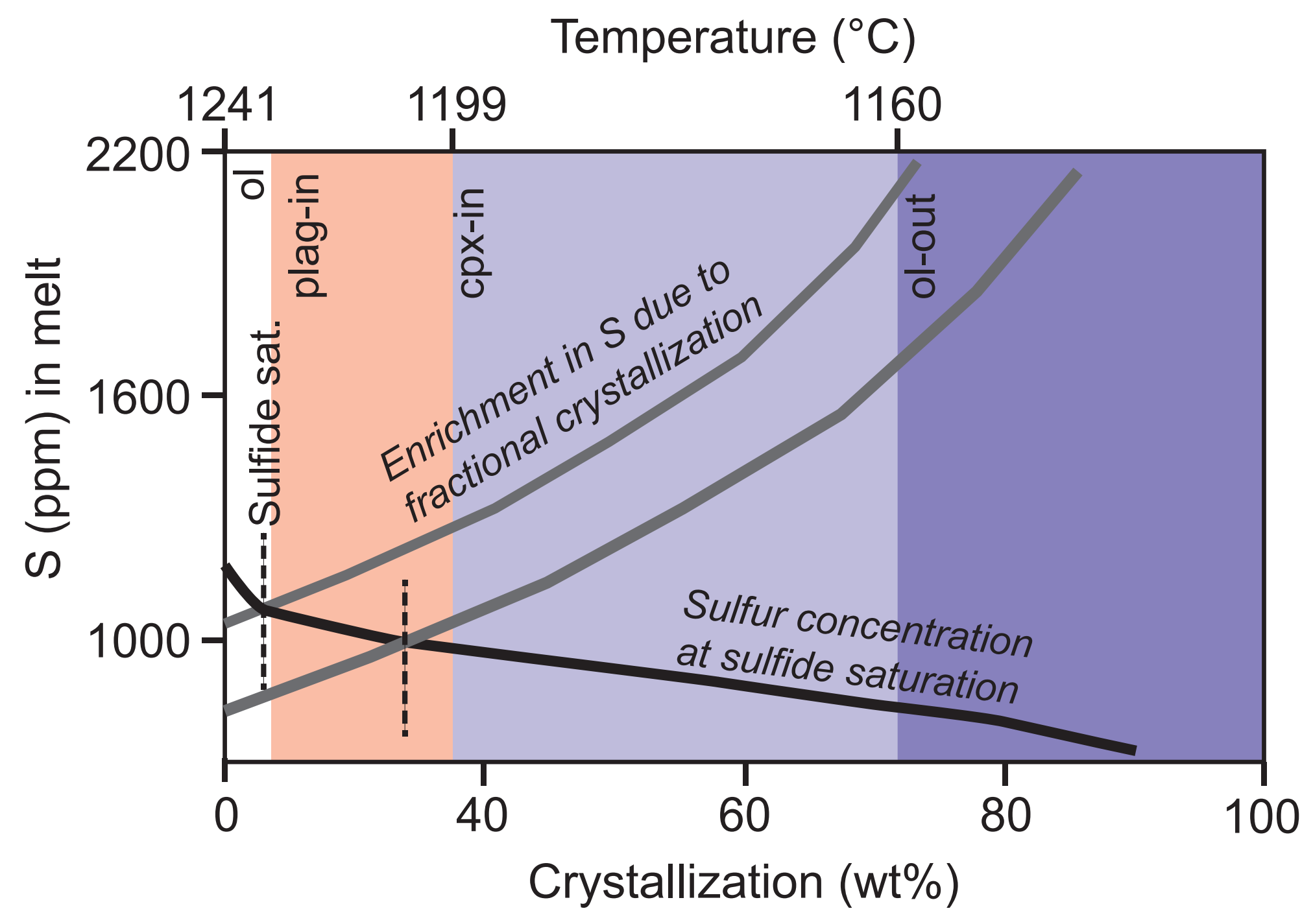




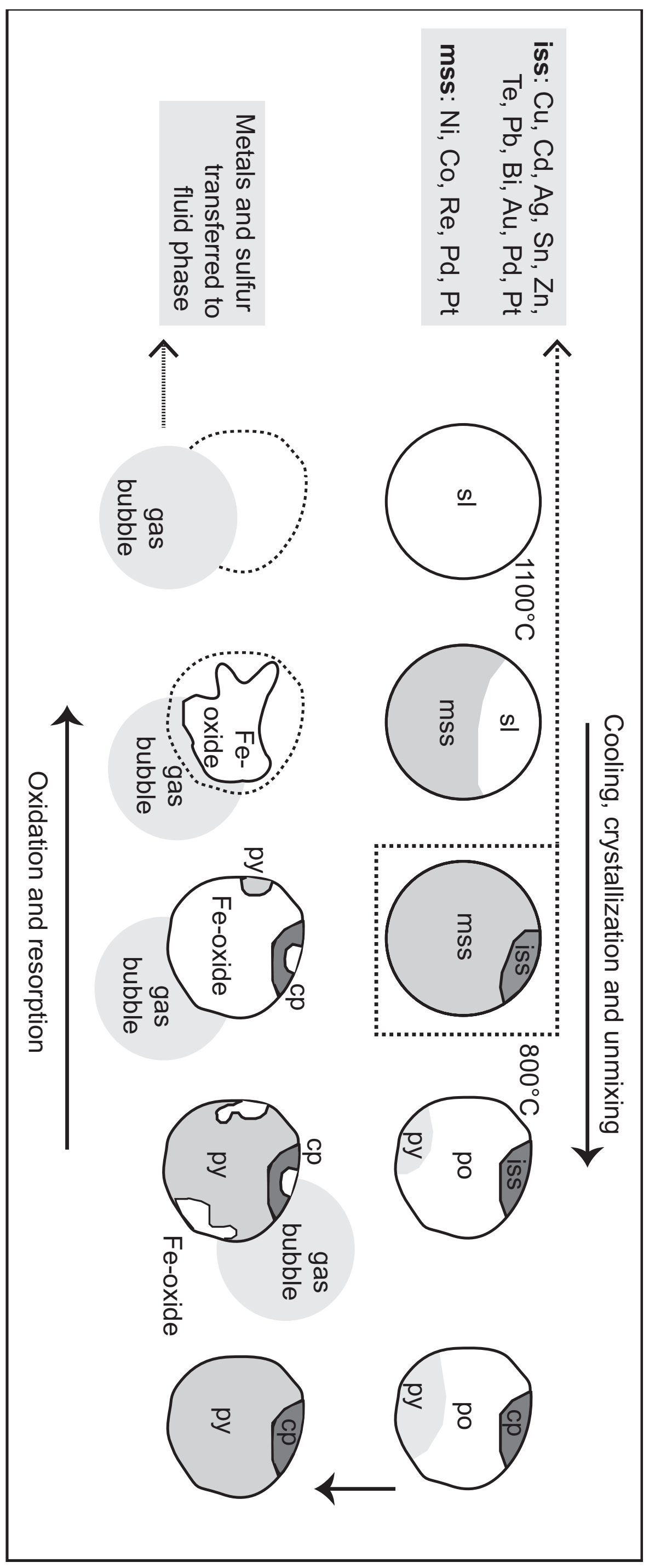



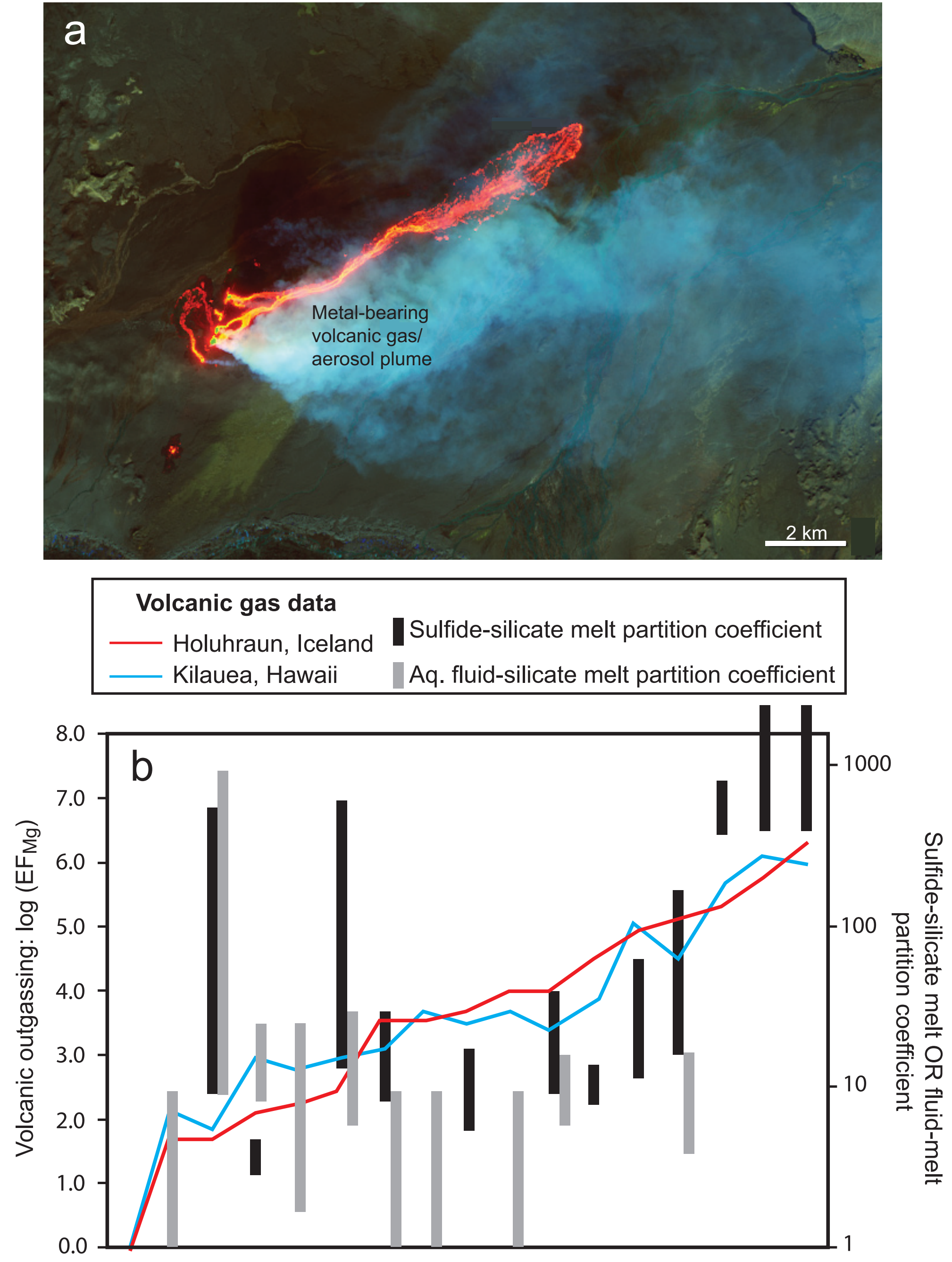

Mg W Cu Zn Mo Ag Sb Sn In As Pb Tl Cd Bi Re Se Te 